\title{
Kualitas SDM, Persepsi Pelaku UMKM, Pemahaman UMKM, Sosialisasi SAK EMKM Terhadap Implementasi SAK EMKM
}

\author{
Rismawandi ${ }^{1}$, Indah Rahayu Lestari ${ }^{2}$, Rinny Meidiyustiani ${ }^{3}$ \\ ${ }^{1,2,3)}$ Universitas Budi Luhur, Jakarta, Indonesia \\ rismawandi@budiluhur.ac.id, indah.rahayu@ budiluhur.ac.id, \\ rinny.meidiyustiani@budiluhur.ac.id
}

*Corresponding Author

Diajukan : 22 Desember 2021

Disetujui : 1 Januari 2022

Dipublikasi : 4 Januari 2022

\begin{abstract}
The purpose of this study was to assess the effect of implementing SAK EMKM for SMEs through four indicators of reflection, namely the quality of human resources as measured by five indicators. Small business perception is measured by seven reflex indicators. MSME understanding is measured by five specific indicators. Socialization of SAK EMKM is measured using five reflection indicators. This type of research is a descriptive quantitative research. The population in this study was 11,746 MSMEs in the food and beverage sector in the city of Tangerang. The survey sample was 100 respondents from MSME actors, obtained using practical or random sampling methods. The data analysis used, with SmartPLS software version 3.2.1, is based on a model that you can think of as an outer model, and an inner model, with hypothesis testing. This study found that the quality of human resources affected the implementation of SAK EMKM, the perception of SAK EMKM actors did not affect the implementation of SAK EMKM, the understanding of SMEs affected the implementation of SAK EMKM, and SAK EMKM socialization did not affect SAK EMKM.
\end{abstract}

Keywords: quality of human resources, perception, understanding, socialization, implementation of SAK EMKM.

\section{PENDAHULUAN}

Pembangunan ekonomi yang dilaksanakan pemerintah Indonesia saat ini ditujukan untuk kesejahteraan rakyat. Salah satunya pembinaan bersama pengembangan Usaha Mikro, Kecil Dan Menengah (UMKM). UMKM suatu kegiatan ekonomi mandiri berskala kecil yang dikelola oleh kelompok masyarakat atau keluarga. UMKM sangat berpengaruh terhadap perekonomian nasional karena dapat menyerap jumlah pengangguran yang besar serta memberikan kontribusi yang tinggi terhadap Produk Domestik Bruto. Menurut Putra dan Kurniawati (2012) dalam Tuti \& Dwijayanti (2016), UMKM banyak menghadapi beberapa kendala, salah satunya adalah pendanaan. Terlalu fokus pada proses produksi dan operasional, sehingga pelaku UMKM tidak memperhatikan pembukuan.

Pemerintah Indonesia telah menetapkan peraturan yang mewajibkan usaha kecil untuk memelihara pembukuan yang baik, seperti Peraturan Pemerintah Republik Indonesia Nomor 17 Tahun 2013 tentang Pelaksanaan Undang-Undang Nomor 20 Tahun 2008 tentang UMKM. Menurut Statistik, (2018), jumlah UMKM di Indonesia mencapai 58,97 juta unit. Jenis usaha kecil 58,91 juta unit, usaha kecil 59.260 unit, usaha menengah 4.987 unit. Berikut informasi dari BPS mengenai grafik pertumbuhan jumlah unit UMKM tahun 2018.

Berdasarkan survei Dinas Koperasi dan UKM Provinsi Banten tahun 2018, jumlah UMKM yang tersebar khusus pada empat kota di provinsi Banten, Kota Tangerang menduduki peringkat tertinggi yaitu jenis usaha mikro sebanyak 633 unit dan 11.746 unit adalah usaha UKM, seperti pada gambar dibawah ini. 


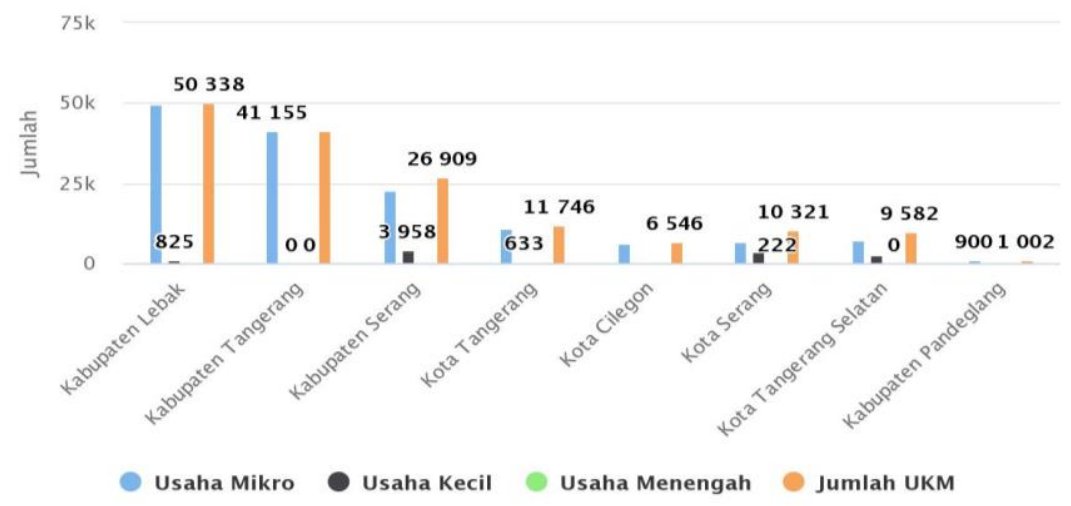

Gambar 1. Jumlah Pertumbuhan UMKM Menurut Kabupaten/Kota di Provinsi Banten

Sumber gambar: Dinas Koperasi dan UKM Provinsi Banten

Kota Tangerang, salah satu wilayah yang memiliki potensi dengan daya saing kuat melalui produk industri kreatifnya. Menurut BPS Kota Tangerang tahun 2018, terdapat tingkat pertumbuhan ekonomi sebesar 5,92\%. Dengan potensi dan kontribusi UMKM yang cukup tinggi terhadap perekonomian, tidak lepas dari kendala yang berkaitan dengan keuangan. Menurut Sulistyowati (2017), laporan keuangan Usaha Kecil Dan Menengah (UKM) masih sangat sederhana, biasanya hanya mencatat transaksi yang sering terjadi pada UKM yang belum memahami Standar Akuntansi Keuangan (SAK).

Peraturan Pemerintah Nomor 17 Tahun 2013, tentang aturan pembukuan bagi pemilik usaha kecil dalam membuat pembukuan yang baik dalam penegakan Undang-Undang No. 20 Tahun 2008 kepada pelaku UMKM. Namun dalam prakteknya masih banyak pelaku UMKM yang belum menyusun laporan akuntansinya sesuai standar. Guna memenuhi kebutuhan pemangku kepentingan UMKM, Dewan Standar Akuntansi Keuangan Ikatan Akuntan Indonesia (DSAK IAI) telah menetapkan akuntansi keuangan untuk entitas yang tidak bertanggung jawab secara publik dari Standar Pelaporan Keuangan Internasional untuk UKM.

Tanggal 18 Mei 2016, DSAK IAI telah menerbitkan Exposure Draft Standar Akuntansi Keuangan Entitas Mikro, Kecil, Dan Menengah (ED SAK EMKM) menjadi Standar Akuntansi Keuangan Entitas Mikro, Kecil, Dan Menengah (SAK EMKM). Kerangka pelaporan keuangannya diharapkan dapat membantu entitas melakukan transisi dari pelaporan keuangan yang berdasarkan kas ke pelaporan keuangan dengan dasar akrual. Penerbitan SAK EMKM ini menjadi salah satu pendorong literasi keuangan untuk UMKM di Indonesia termasuk Kota Tangerang, dapat juga meningkatkan ketersediaan pembiayaan dari industri perbankan, memberikan pedoman penyusunan serta pengembangan pedoman akuntansi bagi usaha kecil di berbagai bidang usaha. Per 1 Januari 2018, SAK EMKM telah berlaku efektif dengan penerapan dini diperkenalkan.

Perbedaan SAK ETAP dan SAK EMKM yang utama adalah ada beberapa standar khusus laporan keuangan SAK EMKM, di antaranya komponen laporan keuangan EMKM yang terdiri dari neraca, laporan laba rugi dan catatan atas laporan keuangan. Aset tetap disusutkan dengan menggunakan metode garis lurus atau saldo menurun tanpa memperhitungkan nilai sisa. Pernyataan komparatif cukup disajikan dengan satu periode sebelumnya. Pengaruh koreksi atas kesalahan karena adanya perubahan kebijakan akuntansi tidak diperlakukan sebagai bagian dari laba rugi pada periode perubahan. Entitas yang menyusun laporan keuangan menggunakan asumsi cash basis mengubah laporan keuangan menjadi akrual dengan melakukan penyesuaian pada akhir periode pelaporan.

Masih banyaknya pelaku UMKM yang mengandalkan modal pribadi untuk usahanya, meskipun pemerintah telah banyak melakukan program di bidang permodalan, seperti Kredit Usaha Rakyat (KUR). Menurut Rudiantoro dan Siregar (2011) dalam Rahmawati \& Puspasari (2017), KUR yang dimaksudkan, untuk memberikan pembiayaan permodalan bagi 
UMKM serta dana untuk membantu mempermudah akses permodalan. Kemenkeu (2015), Pemerintah berupaya mengatasi permasalahan permodalan UMKM dengan memberikan dukungan fasilitas pembiayaan yang berasal dari perbankan. Alasan lain pelaku UMKM belum menggunakan dana atau modal dari pemberi pinjaman kredit karena usahanya terlalu kecil juga terlalu baru untuk menggunakan jumlah kredit yang signifikan, persyaratan pinjaman kreditur masih sangat rumit. Salah satu syaratnya, laporan keuangan perusahaan harus secara akurat mencerminkan keadaan perusahaan saat ini. Beberapa faktor pelaku UMKM untuk menyusun laporan keuangan sesuai SAK EMKM adalah diperlukannya kualitas sumber daya manusia, persepsi pelaku UMKM, pemahaman UMKM dalam menyusun laporan keuangan sesuai SAK EMKM dan sosialisasi SAK EMKM.

Penelitian ini berbeda dengan penelitian sebelumnya, seperti yang diteliti oleh Ketut et al. (2018), berjudul Pengaruh Kualitas Sumber Daya Manusia Dan Ukuran Usaha Terhadap Pemahaman UMKM Dalam Menyusun Laporan Keuangan Berdasarkan SAK EMKM (Studi Kasus pada UMKM di Kecamatan Buleleng). Perbedaan dengan penelitian ini, pada variabel bebas, peneliti menggunakan variabel persepsi pelaku UMKM, pemahaman UMKM, dan sosialisasi SAK EMKM. Penelitian Oktafiani et al. (2018) berjudul Pengaruh Kualitas SDM, Pemanfaatan Teknologi Informasi, Dan Sistem Pengendalian Internal Terhadap Kualitas Laporan Keuangan (Studi Kasus Pada Koperasi Simpan Pinjam Di Kecamatan Buleleng). Perbedaannya, pada variabel bebas, peneliti tidak menggunakan variabel Pemanfaatan Teknologi Informasi, Dan Sistem Pengendalian Internal. Begitu juga pada variabel terikat dan objek penelitian.

Penelitian Badria \& Diana (2018), berjudul Persepsi Pelaku UMKM Dan Sosialisasi SAK EMKM Terhadap Diberlakukannya Laporan Keuangan Yang Berbasis SAK EMKM 1 Januari 2018 (Studi Kasus Pelaku UMKM Se-Malang). Perbedaannya peneliti menambahkan variabel bebas, menggunakan variabel kualitas sumber daya manusia dan pemahaman UMKM. Perbedaannya pada objek penelitian. Selanjutnya Janrosi (2018) dalam penelitiannya berjudul Analisis Persepsi Pelaku UMKM Dan Sosialisasi SAK EMKM Terhadap Diberlakukannya Laporan Keuangan yang Berbasis SAK EMKM (Studi Kasus Pelaku UMKM Kecamatan Sagulung yang terdaftar di Dinas PMP-KUKM Kota Batam). Perbedaannya peneliti menambakan dua variabel bebas, menggunakan variabel kualitas sumber daya manusia dan pemahaman UMKM. Perbedaan lainnya pada objek penelitian.

Penelitian oleh Salmiah et al. (2018), berjudul Pemahaman Pelaku UMKM Terhadap SAK EMKM: Survey Pada UMKM Yang Terdaftar Di Dinas Koperasi Dan UKM Kota Pekanbaru. Perbedaannya terletak pada variabel bebas, peneliti menambahan tiga variabel bebas, yaitu variabel kualitas sumber daya manusia, Persepsi Pelaku UMKM, dan Sosialisasi SAK EMKM. Perbedaan lainnya pada objek penelitian. Menurut Falah Rafiqa (2018), berjudul Analisi Tingkat Pemahaman Dan Tingkat Kesiapan UMKM Dalam Implementasi SAK EMKM Dalam Pelaporan Keuangan Di Kota Padang. Perbedaannya terletak pada variabel bebas, peneliti menambahan tiga variabel bebas, yaitu variabel Kualitas SDM, Persepsi Pelaku UMKM, dan Sosialisasi SAK EMKM. Perbedaan lainnya pada objek penelitian.

Penelitian Kusuma \& Lutfiany (2018) berjudul Persepsi UMKM Dalam Memahami SAK EMKM (Studi Empiris pada UMKM di Kota Bogor). Perbedaan dengan penelitian ini, peneliti melakukan penambahan tiga variabel bebas, menggunakan variabel kualitas sumber daya manusia, pemahaman UMKM, sosialisasi SAK EMKM. Perbedaan lainnya yaitu pada objek penelitian. Dewi et al. (2017), dalam penelitiannya berjudul Pengaruh Sosialisasi SAK ETAP, Tingkat Pendidikan Pemilik, dan Persepsi Pelaku UKM Terhadap Penggunaan SAK ETAP pada UKM di Kecamatan Buleleng. Perbedaannya, peneliti menambahkan dua variabel bebas, menggunakan variabel kualitas sumber daya manusia, Pemahaman UMKM. Perbedaan lainnya pada objek penelitian. Berdasarkan pemaparan latar belakang tersebut, peneliti tertarik melakukan penelitian dengan judul "Analisis Kualitas Sumber Daya 
Manusia, Persepsi Pelaku UMKM, Pemahaman UMKM dan Sosialisasi SAK EMKM Terhadap Implementasi SAK EMKM Pada UMKM Bidang Pangan Di Kota Tangerang".

Kualitas sumber daya manusia adalah kemampuan manusia untuk melaksanakan tugas dan tanggung jawab yang diberikan kepadanya dengan bekal pendidikan, pelatihan, dan pengalaman yang cukup memadai. Penelitian tentang kualitas sumber daya manusia pernah dilakukan oleh Ketut et al. (2018) yang menyatakan bahwa kualitas sumber daya manusia berpengaruh positif dan signifikan terhadap pemahaman UMKM dalam menyusun laporan keuangan berdasarkan SAK EMKM pada UMKM di Kecamatan Buleleng. Menurut Oktafiani et al. (2018) dalam penelitiannya, kualitas sumber daya manusia berpengaruh secara positif terhadap kualitas laporan keuangan. Berdasarkan penjelasan tersebut, maka hipotesis pertama yang diajukan adalah:

$\mathrm{H}_{1}$ : Kualitas sumber daya manusia berpengaruh positif terhadap implementasi SAK EMKM.

Persepsi merupakan proses dimana kita menafsirkan dan mengorganisasikan pola stimulus dalam lingkungan. Penelitian mengenai persepsi pelaku UMKM menurut Badria \& Diana (2018) menyatakan bahwa persepsi pelaku UMKM dapat merubah pemikiran yang semula mengganggap sulit menyusun laporan keuangan menjadi suatu hal yang mudah sehingga pelaku UMKM akan tertib menyusun laporan keuangan yang berbasis SAK EMKM. Sedangkan menurut Janrosi (2018), bahwa persepsi pelaku UMKM tidak berpengaruh signifikan terhadap penggunaan SAK EMKM. Berdasarkan penjelasan tersebut, maka hipotesis kedua yang diajukan adalah:

$\mathrm{H}_{2}$ : Persepsi Pelaku UMKM berpengaruh positif terhadap implementasi SAK EMKM.

Pemahaman bukan kegiatan berpikir semata, melainkan pemindahan letak dari dalam berdiri disituasi atau dunia orang lain. Orang yang memiliki pemahaman akuntansi merupakan orang yang pandai dan mengerti benar tentang akuntansi. Penelitian mengenai pemahaman UMKM menurut Salmiah et al. (2018) bahwa pelaku UMKM yang terdaftar pada Dinas Koperasi dan UKM Kota Pekanbaru sudah memahami bahwa komponen laporan keuangan terdiri dari laporan posisi keuangan, laporan laba rugi, dan catatan atas laporan keuangan. Menurut Falah Rafiqa (2018), bahwa pelaku UMKM di Kota Padang telah paham terhadap dasar-dasar akuntansi. Berdasarkan penjelasan tersebut, maka hipotesis kedua yang diajukan adalah:

$\mathrm{H}_{3}$ : Pemahaman UMKM berpengaruh positif terhadap implementasi SAK EMKM

Sosialisasi SAK EMKM merupakan proses indivdu belajar bagaimana menyesuaikan diri dengan lingkungan tertentu dan bagaimana mengkoordinasikan perilakunya dengan perilaku orang lain dan belajar sesuai dengan peranan dan peraturan yang ditetapkan yakni SAK EMKM. Penelitian mengenai sosialisasi SAK EMKM menurut Kusuma \& Lutfiany (2018), bahwa Sosialisasi SAK EMKM, tingkat pendidikan pemilik, persepsi pelaku UMKM dan pemahaman akuntansi secara simultan berpengaruh positif terhadap implementasi SAK EMKM pada UMKM di Kota Bogor. Menurut Dewi et al. (2017), meyatakan bahwa sosialisasi SAK EMKM berpengaruh signifikan terhadap penggunaan SAK EMKM.

$\mathrm{H}_{4}$ : Sosialisasi SAK EMKM berpengaruh positif terhadap implementasi SAK EMKM

\section{STUDI LITERATUR}

Teori yang menjadi dasar dalam penelitian ini adalah Theory of planned behavior, bagian pengembangan dari theory of reasoned action (teori tindakan beralasan). Planned behavior theory yang dikemukakan oleh Ajzen (1991) dalam Seni \& Ratnadi (2017) menjelaskan bahwa sikap terhadap perilaku sangat penting untuk memperkirakan suatu perbuatan meskipun perlu dipertimbangkan sikap seseorang dalam menguji norma subjektif serta mengukur kontrol perilaku persepsian orang tersebut. Kaitannya dengan penelitian ini adalah dalam suatu usaha ukuran kecil ataupun menengah, pelaku UMKM diwajibkan untuk menyusun laporan keuangan usahanya, karena memudahkan pengelolaan keuangan sehingga memberikan peluang baik kepada pengguna laporan keuangan tentang segala informasi yang 
dimiliki oleh UMKM itu sendiri. Jadi teori ini dapat digunakan untuk menjelaskan keputusan individu dalam menentukan mau atau tidaknya mengimplementasikan SAK EMKM.

Menurut penelitian Ketut et al. (2018), berjudul Pengaruh Kualitas Sumber Daya Manusia dan Ukuran Usaha terhadap Pemahaman UMKM dalam Menyusun Laporan Keuangan Berdasarkan EMKM (Studi Kasus pada UMKM di Kecamatang Buleleng). Hasilnya, kualitas sumber daya manusia dan ukuran usaha berpengaruh positif dan signifikan terhadap pemahaman UMKM dalam menyusun laporan keuangan di Kabupaten Buleleng. Menurut Oktafiani et al. (2018), dalam penelitiannya berjudul Pengaruh Kualitas Sumber Daya Manusia, Pemanfaatan Teknologi Informasi, Dan Sistem Pengendalian Internal Terhadap Kualitas Laporan Keuangan (Studi Kasus Pada Koperasi Simpan Pinjam Di Kecamatan Buleleng. Hasilnya, kualitas sumber daya manusia berpengaruh secara positif terhadap kualitas laporan keuangan, pemanfaatan teknologi informasi berpengaruh positif terhadap kualitas laporan keuangan, dan sistem pengendalian internal berpengaruh positif terhadap kualitas laporan keuangan.

Badria dan Diana (2018), dalam penelitiannya berjudul Persepsi Pelaku UMKM dan Sosialisasi SAK EMKM Terhadap Diberlakukannya Laporan Keuangan yang Berbasis SAK EMKM (Studi Kasus Pelaku UMKM se-Malang). Hasilnya, persepsi pelaku UMKM dan sosialisasi SAK EMKM adalah penggunaan SAK EMKM lebih banyak dan berpengaruh. Penelitian selanjutnya adalah Janrosi (2018) dengan judul Analisis Persepsi Pelaku UMKM dan Sosialisasi SAK EMKM Terhadap Diberlakukannya Laporan Keuangan yang Berbasis SAK EMKM (Studi Kasus Pelaku UMKM Kecamatan Sagulung yang terdaftar di Dinas PMP-KUKM Kota Batam). Hasilnya, Persepsi pelaku UMKM tidak berpengaruh signifikan terhadap penggunaan SAK EMKM.

Penelitian oleh Salmiah et al. (2018), berjudul Pemahaman Pelaku UMKM Terhadap SAK EMKM: Survey Pada UMKM Yang Terdaftar Di Dinas Koperasi Dan UKM Kota Pekanbaru. Hasil penelitiannya bahwa pelaku UMKM yang terdaftar pada Dinas Koperasi dan UKM Kota Pekanbaru sudah memahami bahwa komponen laporan keuangan terdiri dari laporan posisi keuangan, laporan laba rugi, dan catatan atas laporan keuangan namun. Menurut Falah Rafiqa (2018), berjudul Analisi Tingkat Pemahaman Dan Tingkat Kesiapan UMKM Dalam Implementasi SAK EMKM Dalam Pelaporan Keuangan Di Kota Padang. Hasil penelitiannya bahwa pelaku UMKM di Kota Padang telah paham terhadap dasar-dasar akuntansi.

Kusuma \& Lutfiany (2018) dalam penelitiannya berjudul Persepsi UMKM Dalam Memahami SAK EMKM (Studi Empiris pada UMKM di Kota Bogor). Hasilnya bahwa sosialisasi SAK EMKM, tingkat pendidikan pemilik, persepsi pelaku UMKM dan pemahaman akuntansi secara parsial dan simultan berpengaruh positif terhadap penerapan SAK EMKM pada UMKM di Kota Bogor. Menurut Dewi et al. (2017), dalam penelitiannya berjudul Pengaruh Sosialisasi SAK ETAP, Tingkat Pendidikan Pemilik, dan Persepsi Pelaku UKM Terhadap Penggunaan SAK ETAP pada UKM di Kecamatan Buleleng. Hasilnya, bahwa sosialisasi SAK ETAP, tingkat pendidikan pemilik, dan persepsi pelaku UKM berpengaruh positif dan signifikan terhadap penggunaan SAK ETAP.

\section{METODE}

Penelitian ini untuk membuktikan dan menganalisis secara empiris adanya pengaruh kualitas sumber daya manusia, persepsi pelaku UMKM, pemahaman UMKM, dan sosialisasi SAK EMKM sebagai variabel bebas terhadap implementasi SAK EMKM sebagai variabel terikat pada UMKM bagian pangan di Kota Tangerang. Penelitian ini didasarkan data kuantitatif yang dikumpulkan pada tahun 2018 oleh peneliti. Berikut ini adalah desain kerangka penelitian. 


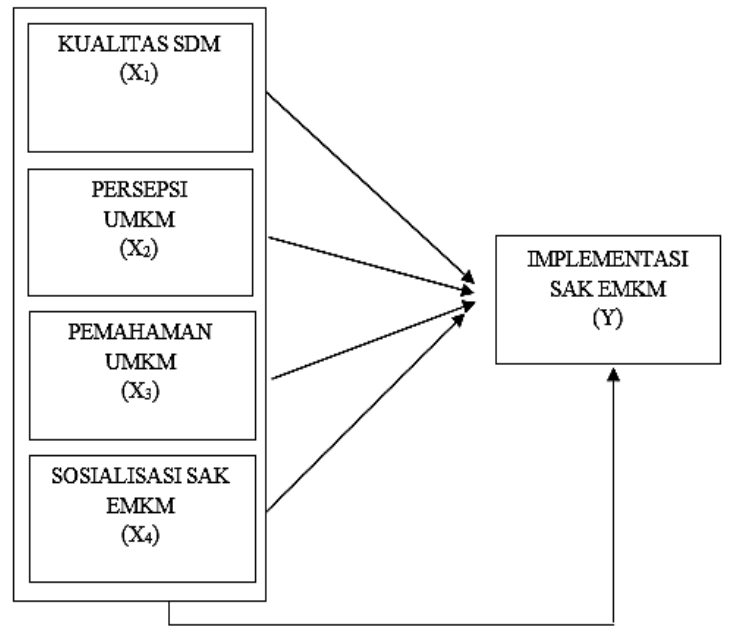

Gambar 2. Kerangka Penelitian

Sumber gambar : Data Penelitian, 2018

Pada gambar 2, model pengukuran dilakukan dengan validitas konvergen, diskriminatif indeks dan reliabilitas gabungan dari blok indikator. Model pertama dalam penelitian ini adalah implementasi SAK EMKM bagi pelaku UMKM, diukur dari tingkat kualitas sumber daya manusia dengan lima indikator, diantaranya pendidikan formal dan non formal, fakta, konversi, klasifikasi. Kedua, persepsi pelaku UMKM diukur dengan lima indkator, yaitu kemudahan menyusun laporan keuangan, menerapkan SAK EMKM, kemudahan pengajuan pinjaman, kemudahan dalam evaluasi perkembangan usaha, pengawasan usaha, pengambilan keputusan, mengetahui kekayaan usaha. Ketiga, pemahaman UMKM diukur dengan lima indikator, yaitu jurnal, buku besar, neraca saldo, penyesuaian, laporan keuangan. Keempat, sosialisasi SAK EMKM diukur dengan lima indikator seperti adanya sosialisasi, menggunakan standar EMKM, lebih sederhana dibandingkan SAK ETAP, memudahkan mengelola usaha, perkembangan usaha.

Metode penelitian ini menggunakan explanative research melalui pendekatan kuantitatif. Merupakan salah satu metode penelitian untuk menguji data berupa angka dan menggunakan statistik Sugiyono (2011). Data survei dalam penelitian ini menggunakan penelusuran kepustakaan dan penelitian lapangan. Pengumpulan data di lapangan dilakukan dengan survei menggunakan kuesioner. Kuesioner terdiri dari dua bagian dalam rancangan uji model pengukuran, yang pertama mengenai informasi UMKM dan yang kedua mengenai persepsi responden terhadap tiap variabel dalam model.

Informasi UMKM mencakup kategori seperti jenis kelamin pemilik, tahun berdiri, umur pemilik, dan pendidikan pemilik. Bagian kedua dari persepsi, diperlukan penentuan responden untuk setiap item. Instrumen berupa kuesioner yang digunakan berdasarkan konsep skala Likert. Penyusunan kalimat pernyataan yang akan menghasilkan hal positif dan negatif saling berhubungan dengan variabel penelitian. Responden diminta untuk menyatakan apakah mereka setuju atau tidak setuju dalam menanggapi pernyataan yang diajukan peneliti atas dasar persepsi masing-masing responden. Sangat Setuju (SS), Setuju (S), Netral (N), Tidak Setuju (TS), dan Sangat Tidak Setuju (STS).

Bobot nilai untuk jawaban Sangat Setuju (SS) diberikan nilai 5 (lima), dan menurun sampai jawaban Sangat Tidak Setuju (STS) diberikan nilai 1 (satu). Peneliti memilih skala Likert dengan angka ganjil, skala menampilkan pilihan nilai tengah yaitu Netral. Responden mungkin saja merasa benar-benar netral terhadap suatu topik, sehingga tanpa pilihan nilai tengah tersebut dapat menimbulkan bias bagi responden antara memilih jawaban yang cenderung negatif atau positif, sehingga tanpa pilihan. Namun, perdebatan tentang penggunaan tengah nilai masih berlangsung. Menjadi kebijakan peneliti untuk menentukan model mana yang sesuai (Losby \& Wetmore, 2012).

Subjek survei ini adalah UMKM sub sektor pangan, terdaftar di Dinas Koperasi dan 
UMKM Kota Tangerang tahun 2018 sebanyak 11.746 unit. UMKM di Kota Tangerang ini memiliki 11.079 usaha mikro, 633 usaha kecil dan menengah, 34 usaha kecil dan menengah, yang termasuk dalam 11 kecamatan. Seperti pada tabel di bawah ini.

Tabel 1. Data UMKM Kota Tangerang Tahun 2018

\begin{tabular}{|c|l|c|c|c|c|}
\hline \multirow{2}{*}{ NO } & \multirow{2}{*}{ KECAMATAN } & \multicolumn{3}{|c|}{ UMKM } & \multirow{2}{*}{ JUMLAH } \\
\cline { 3 - 5 } & & MIKRO & KECIL & MENENGAH & \\
\hline 1 & Tangerang & 585 & 55 & 5 & 645 \\
\hline 2 & Batu Ceper & 556 & 22 & 0 & 578 \\
\hline 3 & Benda & 291 & 30 & 1 & 322 \\
\hline 4 & Neglasari & 227 & 27 & 0 & 254 \\
\hline 5 & Cipondoh & 444 & 141 & 6 & 591 \\
\hline 6 & Pinang & 840 & 38 & 3 & 881 \\
\hline 7 & Ciledug & 353 & 83 & 4 & 440 \\
\hline 8 & Karang Tengah & 342 & 59 & 5 & 406 \\
\hline 9 & Larangan & 737 & 80 & 5 & 822 \\
\hline 10 & Karawaci & 829 & 19 & 3 & 851 \\
\hline 11 & Cibodas & 3962 & 16 & 1 & 3979 \\
\hline 12 & Jatiuwung & 1264 & 32 & 0 & 1296 \\
\hline 13 & Periuk & 649 & 31 & 1 & 681 \\
\hline & JUMLAH & 11.079 & 633 & 34 & 11.746 \\
\hline
\end{tabular}

Sumber tabel: Dinas Koperasi dan UKM Kota Tangerang, 2018

Metode pengambilan sampel menggunakan teknik non-probability sampling, dikenal sebagai random sampling, suatu metode pengambilan sampel yang nyaman. Pengambilan sampel secara acak (convenient sampling) merupakan proses pengambilan sampel di mana sampel dipilih dari orang atau entitas yang mudah dijangkau atau paling mudah (Santoso \& Tjiptono, 2001). Sampel dalam survei ini mencakup 100 pemilik UMKM. Analisis data yang digunakan, dengan software SmartPLS versi 3.2.1 berdasarkan model pengukuran (model eksternal), struktur model (model internal), dan pengujian hipotesis (Ghozali, 2014).

\section{HASIL}

Desain model pengukuran menampilkan model outdoor. Cross-loading adalah korelasi antara konstruk dan objek pengukuran yang lebih besar dari ukuran konstruk lainnya. Ini menunjukkan bahwa struktur laten lebih mudah diprediksi daripada ukuran blok lainnya (Ghozali, 2014). Hasil uji cross-loading ditunjukkan pada Tabel 2 di bawah ini.

Tabel 2. Tabel Cross Loading

\begin{tabular}{|c|c|c|c|c|c|}
\hline & X1 & X2 & X3 & X4 & Y \\
\hline X1_1 & 8.432 & & & & \\
\hline X1_2 & 12.096 & & & & \\
\hline X1_3 & 19.068 & & & & \\
\hline X1_4 & 16.358 & & & & \\
\hline X1_5 & 8.790 & & & & \\
\hline X2_1 & & 12.979 & & & \\
\hline X2_2 & & 11.427 & & & \\
\hline X2_3 & & 17.883 & & & \\
\hline X2_4 & & 11.282 & & & \\
\hline X2_5 & & 7.595 & & & \\
\hline X2_6 & & 13.969 & & & \\
\hline X2_7 & & 9.787 & & & \\
\hline X3_1 & & & 9.546 & & \\
\hline X3_2 & & & 10.256 & & \\
\hline X3_3 & & & 8.855 & & \\
\hline
\end{tabular}

\begin{tabular}{|c|c|c|c|c|c|}
\hline & X1 & X2 & X3 & X4 & Y \\
\hline X3_4 & & & 13.891 & & \\
\hline X3_5 & & & 10.047 & & \\
\hline X4_1 & & & & 10.627 & \\
\hline X4_2 & & & & 15.886 & \\
\hline X4_3 & & & & 9.343 & \\
\hline X4_4 & & & & 13.357 & \\
\hline X4_5 & & & & 16.869 & \\
\hline Y_1 & & & & & 6.576 \\
\hline Y_2 & & & & & 12.126 \\
\hline Y_3 & & & & & 10.940 \\
\hline Y_7 & & & & & 8.041 \\
\hline Y_8 & & & & & 1.085 \\
\hline Y_9 & & & & 12.255 \\
\hline Y_10 & & & & 7.847 \\
\hline
\end{tabular}

Sumber tabel : Data Penelitian, 2018

Pada tabel 2.Cross Loading, jika indikator memiliki nilai di atas 0,70, maka hasilnya dianggap standar dan tidak perlu diulang. Pengukuran refleksi individu dikatakan tinggi jika korelasi antara konfigurasi yang diukur dengan penilaian kepribadian individu nilainya lebih besar dari $70 \%$. Namun, jika tahap awal penelitian nilai skala pengukuran dengan nilai beban 
adalah antara 0,50 dan 0,60 maka dinilai Cukup (Ghozali, 2014).

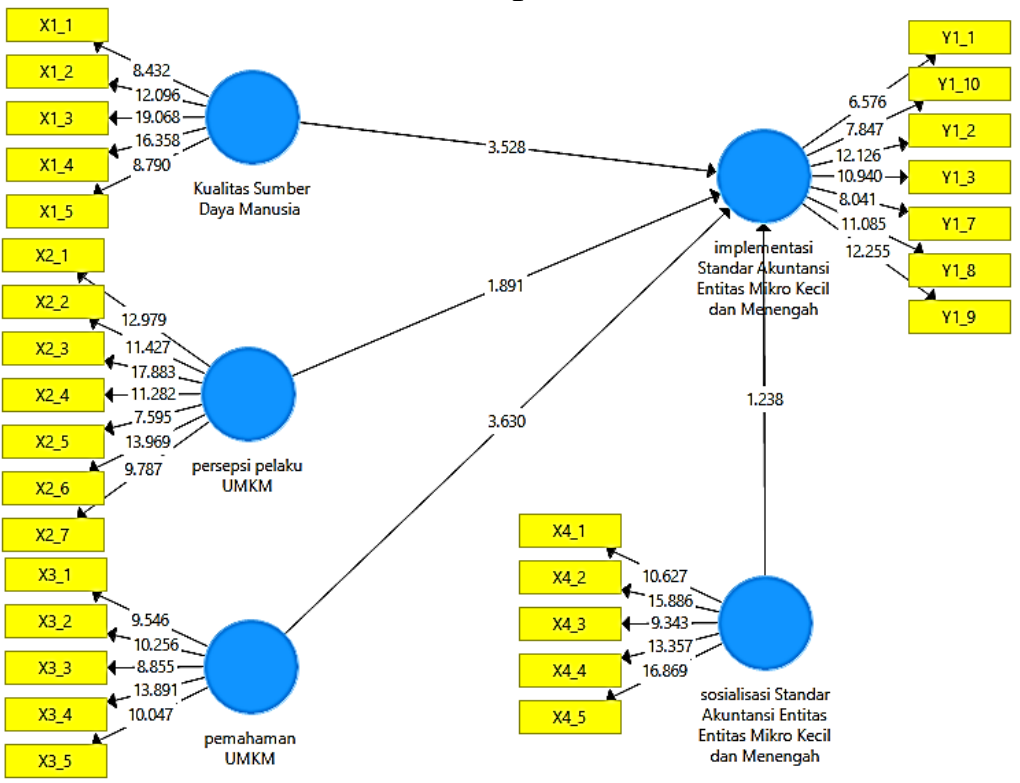

Gambar 3. Convergent Validity

Sumber gambar : Hasil Penelitian, 2018

Average Variance Extracted (AVE) dan laten untuk menilai validitas diskriminasi, dengan membandingkan nilai akar kuadrat dari nilai AVE untuk setiap konfigurasi dengan korelasi antar konfigurasi dan konfigurasi lainnya dalam model korelasi. Ketika nilai rata-rata akar kuadrat dari AVE setiap konfigurasi lebih besar dari korelasi antara konfigurasi dalam model dan konfigurasi lainnya, maka validitas diskriminan dinyatakan Baik (Fornell \& Larcker, 1981). Hasil uji AVE ditunjukkan pada gambar 5 di bawah ini.

\section{Construct Reliability and Validity}

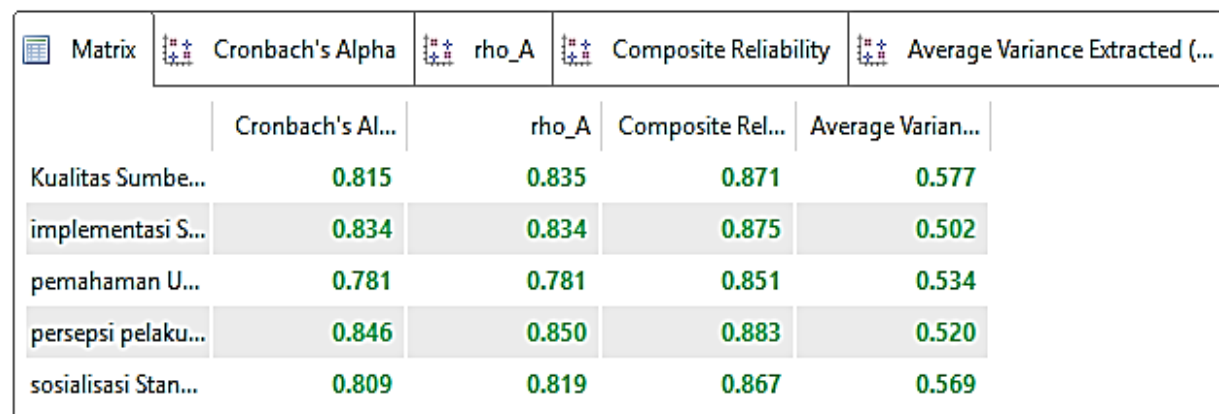

Gambar 4. Average Variance Extracted (AVE)

Sumber gambar: Hasil Penelitian, 2018

Berdasarkan gambar 4, diperoleh hasil bahwa nilai AVE lebih besar 0,50 untuk semua konfigurasi. Jika model yang diuji tidak memiliki masalah validitas konvergensi, maka konfigurasi valid. Langkah selanjutnya mengukur validitas konvergen pada suatu skala, apakah tinggi atau tidak.

Hal ini untuk mempertimbangkan nilai Cronbach alpha. Composite reliability $(\mathrm{pc})$ digunakan untuk mengukur nilai reliabilitas sebenarnya dari suatu variabel, dan Cronbach alpha untuk mengukur nilai reliabilitas terendah (lebih rendah) dari suatu variabel, sehingga nilai composite reliability (pc) sebesar 0,60 dan Cronbach alpha sebesar 0,60. Menurut Sarstedt et al. (2020), untuk membutuhkan skor kepercayaan gabungan harus lebih besar dari 0,70 atau 0,60 , jika penelitian ini eksploratori. Hasil uji reliabilitas komposit menunjukkan nilai yang sangat baik di atas 0,70 . Di bawah ini adalah nilai keandalan komposit pada output. 
Construct Reliability and Validity

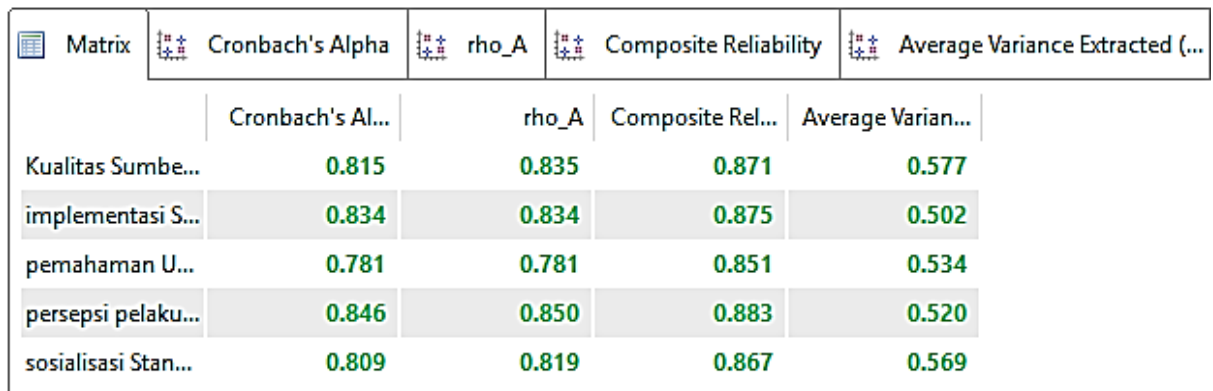

Gambar 5. Cronbach's Alpha dan Composite Reliability

Sumber gambar: Hasil Penelitian, 2018

Berdasarkan Gambar 5, hasilnya menunjukkan nilai composite reliability, Cronbach's alpha, lebih besar dari 0,70 di semua konfigurasi. Dikarenakan semua konfigurasi model di atas memenuhi kriteria uji reliabilitas dan memiliki reliabilitas sangat baik, maka disimpulkan nilai keandalan terendah dari konfigurasi Pemahaman UMKM adalah 0,851. Untuk menguji seberapa kuat variabel ekstrinsik dan intrinsik bergantung pada model dasar ini, peneliti menguji besarnya nilai R-Square masing-masing variabel intrinsik, seperti yang ditunjukkan pada gambar 7, dibawah ini.

\section{R Square}

\begin{tabular}{|c|c|c|c|}
\hline \multirow[t]{2}{*}{ Matrix } & 㩰葉 R Square & \multicolumn{2}{|c|}{ 抨辛 R Square Adjusted } \\
\hline & & R Square & R Square Adjus.. \\
\hline \multicolumn{2}{|c|}{ implementasi S... } & 0.754 & 0.744 \\
\hline
\end{tabular}

Gambar 6. R Square Adjusted

Sumber gambar: Hasil Penelitian, 2018

Berdasarkan gambar 6, nilai variabel R-Square untuk penerapan standar akuntansi UKM digambarkan sebesar 74,4\%. Setelah itu, 25,6\% sisanya dipengaruhi oleh variabel atau faktor lain selain model survei. Langkah selanjutnya adalah memprediksi hubungan kausalitas (hubungan sebab-akibat) antar variabel laten atau variabel yang tidak dapat diukur secara langsung. Pada uji structural model (inner model) menggunakan bantuan prosedur bootstrapping dalam SmartPLS.

Hal ini dapat dilihat dari koefisien jalur (path coefficient) yang menggambarkan kekuatan hubungan antar konstruk. Tanda dalam path coefficient harus sesuai dengan teori yang dihipotesiskan, untuk menilai sigifikan path coefficient dapat dilihat dari t test (critical ratio) yang diperoleh dari proses bootstrapping (resampling method). Imam \& Hengki (2012) menyatakan bahwa bootstrapping adalah proses atau teknik re-sampling statistik, dimana responden secara acak diganti dari sampel asli berulang-ulang sampai pengamatan diperoleh. Seperti pada output evaluasi dibawah ini. 


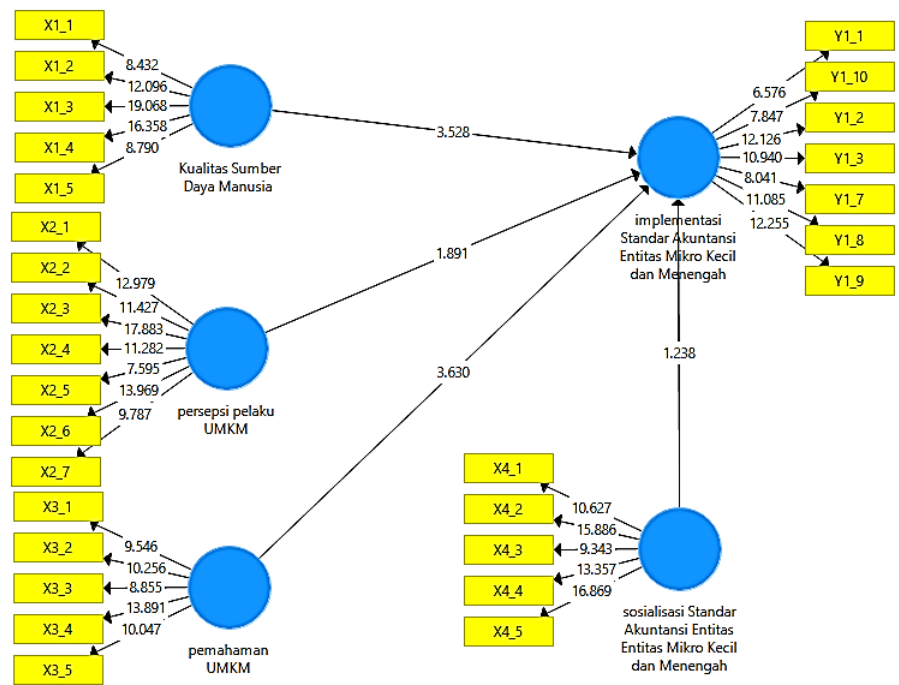

Gambar 7. Evaluasi Inner Mode, Bootstrapping

Sumber gambar: Hasil Penelitian, 2018

Diatas merupakan hasil analisis Partial Least Square Inner Mode, Bootstrapping dalam penelitian ini. Pada uji diatas tersebut dapat dilihat dari koefisien jalur (path coefficient) yang menggambarkan kekuatan hubungan antar konstruk, jika terdapat variabel dengan nilai T-statistik lebih besar dari 1,96 maka dapat dinyatakan berpengaruh.

Nilai T-statistik variabel Kualitas sumber daya manusia terhadap implementasi SAK EMKM, dengan nilai T-statistik sebesar 3,528 lebih besar dari 1,96 maka dinyatakan berpengaruh. Nilai T-statistik variabel Persepsi pelaku UMKM adalah 1,891 lebih kecil dari 1,96, maka dinyatakan tidak berpengaruh terhadap implementasi SAK EMKM. Nilai Tstatistik variabel pemahaman UMKM sebesar 3,630 yang lebih besar dari 1,96, maka dapat dinyatakan berpengaruh. Nilai T-statistik variabel Sosialisasi SAK EMKM sebesar 1,238 lebih kecil dari 1,96, maka dinyatakan tidak berpengaruh terhadap implementasi SAK EMKM. Dibawah ini adalah nilai koefisien jalur atau besarnya hubungan/pengaruh konstruk laten.

\section{Path Coefficients}

\begin{tabular}{|c|c|c|c|c|c|c|c|c|c|}
\hline \multicolumn{2}{|c|}{ 囯 Mean, STDEV, T-Values, P-Va... } & \multicolumn{2}{|c|}{ 同 Confidence Intervals } & \multicolumn{2}{|c|}{ 葍 Confidence Intervals Bias C.... } & Samples & Copy to Clipboard: & Excel Format & R Format \\
\hline & Original Sampl.... & Sample Mean (.... & Standa & ard Devia... & TStatistics $(\mid 0 . .$. & P Values & & & \\
\hline Kualitas Sumbe.... & 0.343 & 0,347 & & 0.097 & 3.528 & 0.000 & & & \\
\hline pemahaman U... & 0.315 & 0.311 & & 0.087 & 3.630 & 0.000 & & & \\
\hline persepsi pelaku... & 0.216 & 0.222 & & 0.114 & 1.891 & 0.059 & & & \\
\hline sosialisasi Stan... & 0.103 & 0.097 & & 0.083 & 1.238 & 0.216 & & & \\
\hline
\end{tabular}

Gambar 8. Path Coefficient Bootstrapping

Sumber gambar: Hasil Penelitian, 2018

Berdasarkan gambar 8, hasil uji $\mathrm{T}$ (2-tailed) dengan tingkat nilai signifikansi 5\% menunjukkan bahwa:

Hipotesis pertama, nilai original sample estimete LS adalah 0,343 dengan nilai signifikansi diatas 5\%, ditunjukkan dengan nilai t statistik 3.528 lebih besar nilai t-tabel 2.0017. Nilai original sample estimate mengindikasikan bahwa kualitas SDM berpengaruh positif terhadap implementasi SAK EMKM. Berdasarkan hasil regresi tersebut disimpulkan bahwa hipotesis pertama diterima.

Hipotesis kedua, nilai original sample estimete LS adalah 0.216 dengan nilai signifikansi diatas 5\% ditunjukkan dengan nilai t statistik 1.891 lebih kecil nilai t-tabel 2.0017. Nilai original sample estimate mengindikasikan bahwa persepsi pelaku UMKM 
tidak berpengaruh positif terhadap implementasi SAK EMKM. Berdasarkan hasil regresi tersebut disimpulkan bahwa hipotesis kedua ditolak.

Hipotesis ketiga, nilai original sample estimete LS adalah 0.315 dengan signifikansi diatas 5\% ditunjukkan dengan nilai t statistik 3.630 lebih besar nilai t-tabel 2.0017. Nilai original sample estimate mengindikasikan bahwa pemahaman UMKM berpengaruh positif terhadap implementasi SAK EMKM. Berdasarkan hasil regresi tersebut disimpulkan bahwa hipotesis ketiga diterima.

Hipotesis keempat, nilai original sample estimete LS adalah 0.103 dengan signifikansi diatas 5\% ditunjukkan dengan nilai t statistik 1.238 lebih kecil nilai t-tabel 2,0017. Nilai original sample estimate mengindikasikan bahwa sosialisasi SAK EMKM tidak berpengaruh positif terhadap implementasi SAK EMKM. Berdasarkan hasil regresi tersebut disimpulkan bahwa hipotesis keempat ditolak.

\section{PEMBAHASAN}

Berdasarkan hasil penelitian dan pembahasan yang dilakukan serta didukung oleh beberapa alasan, maka peneliti menarik kesimpulan bahwa:

Variabel kualitas sumber daya manusia berpengaruh signifikan terhadap Penerapan SAK EMKM. Hasil penelitian ini sejalan dengan penelitian yang dilakukan oleh Ketut et al. (2018) yang mendukung bahwa kualitas sumber daya manusia berpengaruh positif dan signifikan terhadap pemahaman UMKM dalam menyusun laporan keuangan. Begitu juga menurut Oktafiani et al. (2018), dalam hasil penelitiannya adalah kualitas sumber daya manusia berpengaruh secara positif terhadap kualitas laporan keuangan. Sehingga dengan meningkatnya kualitas sumber daya manusia pada UMKM maka penerapan SAK EMKM juga akan meningkat. Kualitas sumber daya manusia dengan pendidikan formal terakhir dan pendidikan non formal seperti kursus atau seminar yang diikuti oleh pemilik UMKM akan memudahkan pelaku UMKM memahami akuntansi, terutama pendidikan yang diambil adalah jurusan akuntansi.

Variabel persepsi pelaku UMKM tidak berpengaruh terhadap implementasi SAK EMKM. Hasil penelitian ini tidak mendukung dengan penelitian Badria \& Diana (2018), yang menyatakan bahwa persepsi pelaku UMKM berpenaruh terhadap penggunaan SAK EMKM. Namun penelitian ini sejalan dengan penelitiannya Janrosi (2018) yang menyatakan bahwa persepsi pelaku UMKM tidak berpengaruh signifikan terhadap penggunaan SAK EMKM. Faktor persepsi pelaku UMKM tidak berpengaruh terhadap implementasi SAK EMKM dikarenakan adanya penerimaan dan evaluasi oleh pelaku UMKM yang belum menganggap penting SAK EMKM untuk membuat laporan keuangan. Selama ini pelaku UMKM menilai sulit untuk membuat laporan keuangan sesuai SAK EMKM. Sehubungan dengan hal tersebut diatas, diperlukan sosialisasi dari pihak-pihak terkait untuk memperkenalkan SAK EMKM dan mengubah persepsi para pengusaha UMKM agar dapat membuat laporan keuangan sesuai SAK EMKM, sebagai penerimaan dan evaluasi untuk menjadikan usaha pelaku UMKM lebih baik dari sebelumnya.

Variabel pemahaman UMKM berpengaruh terhadap penerapan SAK EMKM. Hasil penelitian ini sesuai dengan penelitian Salmiah et al., (2018), yang menyatakan bahwa pelaku UMKM yang terdaftar pada Dinas Koperasi dan UKM Kota Pekanbaru sudah memahami bahwa komponen laporan keuangan terdiri dari laporan posisi keuangan, laporan laba rugi, dan catatan atas laporan keuangan namun. Penelitian ini juga didukung oleh Falah Rafiqa (2018), yang menyatakan bahwa pelaku UMKM di Kota Padang telah paham terhadap dasardasar akuntansi. Maksud pemahaman UMKM disini adalah pemahaman para pemilik UMKM terhadap penerapan SAK EMKM. Semakin besar pemahaman UMKM dalam menyusun laporan keuangan maka semakin besar penerapan SAK EMKM pada UMKM.

Variabel Sosialisasi SAK EMKM tidak mempengaruhi penerapan SAK EMKM. Hasil penelitian ini tidak sejalan dengan penelitian Kusuma \& Lutfiany (2018) yang menyatakan bahwa sosialisasi SAK EMKM berpengaruh positif terhadap penerapan SAK EMKM pada 
UMKM di Kota Bogor. Juga tidak sejalan dengan penelitian Dewi et al. (2017), yang menyatakan bahwa sosialisasi SAK ETAP berpengaruh positif dan signifikan terhadap penggunaan SAK ETAP. Hasil penelitian bahwa sosialisasi SAK EMKM tidak berpengaruh terhadap implementasi SAK EMKM dikarenakan banyak UMKM yang belum pernah mengikuti sosialisasi atau pelatihan khusus SAK EMKM. Meskipun sebagian besar UMKM belum pernah mengikuti kegiatan tersebut, ternyata masih banyak pelaku UMKM yang telah mengikuti sosialisasi atau pelatihan akuntansi seperti penyusunan laporan keuangan sederhana. Secara tidak langsung penyusunan laporan keuangan yang diajarkan merupakan laporan keuangan berdasarkan SAK EMKM, namun pelaku UMKM masih merasa bingung dan tidak mengetahui istilah SAK EMKM.

\section{KESIMPULAN}

Berdasarkan hasil pembahasan penelitian ini, maka peneliti memberikan kesimpulan bahwa kualitas sumber daya manusia yang baik dapat meningkatkan kemampuan menyerap (termasuk akuisisi, asimilasi, transformasi, dan eksploitasi) dari pengetahuan baru. Dengan bekal pendidikan dan pelatihan yang cukup dan memadai dari sumber daya manusia, maka dapat melakukan tugas dan tanggung jawab untuk menyusun laporan keuangan berdasarkan standar SAK EMKM.

Persepsi pelaku UMKM masih belum menganggap penting SAK EMKM, dikarenakan kurangnya infromasi yang diterima oleh pelaku UMKM untuk membuat laporan keuangan usaha sehingga pelaku UMKM selama ini menilai sulit membuat laporan keuangan sesuai SAK EMKM. Oleh karena itu, diperlukan sosialisasi dari pihak-pihak terkait untuk memperkenalkan SAK EMKM dan mengubah persepsi para pengusaha UMKM agar dapat membuat laporan keuangan sesuai SAK EMKM, sebagai penerimaan dan evaluasi untuk menjadikan usaha pelaku UMKM lebih baik dari sebelumnya.

Pemilik UMKM mengimplementasikan SAK EMKM apabila pemilik UMKM memiliki pemahaman mengenai informasi akuntansi yang dapat digunakan dalam menyusun laporan keuangan usaha. Perlunya pelatihan yang kontinyu guna meningkatkan pemahaman pemilik UMKM mengenai akuntansi dan pelaporan keuangan.

Sosialisasi SAK EMKM dalam bentuk pelatihan dan seminar mengenai pembuatan laporan keuangan yang dilakukan oleh Ikatan Akuntansi Indonesia (IAI) bekerja sama dengan Dinas Koperasi dan UMKM setempat harus menggunakan pola bahasa yang dapat dipahami dan metode pelatihan yang efektif sehingga sosialisasi ini dapat punya pengaruh untuk pemilik UMKM.

\section{REFERENSI}

Badria, N., \& Diana, N. (2018). Persepsi Pelaku UMKM Dan Sosialisasi SAK EMKM Terhadap Diberlakukannya Laporan Keuangan Yang Berbasis SAK EMKM 1 Januari 2018 (Studi Kasus Pelaku UMKM Se-Malang). Jurnal Ilmiah Riset Akuntansi, 7(01).

Dewi, N. A. P. U., Yuniarta, G. A., AK, S. E., \& Wahyuni, M. A. (2017). Pengaruh Sosialisasi SAK ETAP, Tingkat Pendidikan Pemilik, dan Persepsi Pelaku UKM Terhadap Penggunaan SAK ETAP pada UKM di Kecamatan Buleleng. JIMAT (Jurnal Ilmiah Mahasiswa Akuntansi) Undiksha, 7(1).

Falah Rafiqa. (2018). ANALISIS TINGKAT PEMAHAMAN DAN TINGKAT KESIAPAN UMKM DALAM IMPLEMENTASI SAK EMKM DALAM PELAPORAN KEUANGAN DI KOTA PADANG.

Fornell, C., \& Larcker, D. F. (1981). SEM with Unobservable Variables and Measurement Error: Algebra and Statistics. In Journal of Marketing Research (Vol. 18, Issue 3, pp. 1-16).

Ghozali, I. (2014). Structural equation modeling metode alternatif dengan partial least square (PLS) dilengkapi Software SmartPLS 3.00 Xistat 2014 dan WarpPLS 4.0. In Edisi ke-4. Semarang: Badan Penerbit Universitas Diponegoro Semarang.

Imam, G., \& Hengki, L. (2012). Partial Least Squares: Konsep, Teknik Dan Aplikasi Smartpls 2.0 M3 Untuk Penelitian Empiris. Badan Penelitian Universitas Diponegoro Semarang.

Janrosi, V. S. E. (2018). Persepsi Pelaku UMKM Dan Sosialisasi SAK EMKM Terhadap Diberlakukannya Laporan Keuangan Yang Berbasis SAK EMKM 1 Januari 2018. Jurnal Akuntansi Keuangan Dan Bisnis, 11(1), 55-66. 
Ketut, S. E., Putu, D. M. D. E., \& Nyoman, Y. P. (2018). Pengaruh Kualitas Sumber Daya Manusia dan Ukuran Usaha Terhadap Pemahaman UMKM dalam Menyusun Laporan Keuangan Berdasarkan SAK EMKM (Studi Kasus pada UMKM di Kecamatan Buleleng). JIMAT (Jurnal Ilmiah Mahasiswa Akuntansi), 9(3), 166-178.

Keuangan, K. (2015). Keputusan menteri keuangan no. 466 tahun 2015 tentang rencana strategis Kemenkeu 2015-2019. Jakarta: Kementerian Keuangan.

Kusuma, I. C., \& Lutfiany, V. (2018). SMEs Perceptions in Understanding SAK EMKM. Jurnal Akunida, 4.

Losby, J., \& Wetmore, A. (2012). CDC coffee break: Using Likert Scales in evaluation survey work. Centers for Disease Control and Prevention.

OKTAFIANI, R., Sulindawati, N. L. G. E., Ak, S. E., \& Julianto, I. P. (2018). Pengaruh Kualitas Sumber Daya Manusia, Pemanfaatan Teknologi Informasi, Dan Sistem Pengendalian Internal Terhadap Kualitas Laporan Keuangan (Studi Kasus Pada Koperasi Simpan Pinjam Di Kecamatan Buleleng). JIMAT (Jurnal Ilmiah Mahasiswa Akuntansi) Undiksha, 8(2).

Rahmawati, T., \& Puspasari, O. R. (2017). Implementasi Sak Etap Dan Kualitas Laporan Keuangan Umkm Terkait Akses Modal Perbankan. Jurnal Kajian Akuntansi, 1(1), 49-62. https://doi.org/10.33603/jka.v1i1.510

Salmiah, N., Nanda, S. T., \& Adino, I. (2018). Pemahaman pelaku UMKM terhadap SAK EMKM: Survey pada UMKM yang terdaftar di Dinas Koperasi dan UKM Kota Pekanbaru. Akuntansi Dewantara, 2(2), 194-204.

Santoso, S., \& Tjiptono, F. (2001). Riset Pemasaran: konsep dan aplikasi dengan SPSS. In PT. Elex Media Komputindo, Jakarta.

Sarstedt, M., Ringle, C. M., \& Hair, J. F. (2020). Handbook of Market Research. In Handbook of Market Research (Issue September). https://doi.org/10.1007/978-3-319-05542-8

Seni, N. N. A., \& Ratnadi, N. M. D. (2017). Theory of Planned Behavior Untuk Memprediksi Niat Berinvestasi. E-Jurnal Ekonomi Dan Bisnis Universitas Udayana, 12, 4043. https://doi.org/10.24843/eeb.2017.v06.i12.p01

Statistik, B. P. (2018). Statistics Indonesia. Jakarta: Statistics Indonesia.

Sugiyono, P. (2011). Metodologi penelitian kuantitatif kualitatif dan R\&D. In Alpabeta, Bandung.

Sulistyowati, Y. (2017). Pencatatan Pelaporan Keuangan Umkm (Study Kasus Di Kota Malang). Referensi: Jurnal Ilmu Manajemen Dan Akuntansi, $5(2), \quad 49$. https://doi.org/10.33366/ref.v5i2.831

Tuti, R., \& Dwijayanti, P. F. (2016). AKTOR-FAKTOR YANG MEMPENGARUHI PEMAHAMAN UMKM DALAM MENYUSUN LAPORAN KEUANGAN BERDASARKAN SAK ETAP. Jurnal Akuntansi Kontemporer (Jako), 8, 98-107. 